\section{NFUD har ny nettside og ny logo}

Årets Generalforsamling i NFUD bestemte seg for å presentere NFUD i fremtiden med en mer tidsriktig internettside.
Etter en betydelig arbeidsinnsats i løpet av sommeren av spesielt Dan Skoglund fra styret, finnes den nye nettsiden nå under den tidligere adressen http://nfud.no/.
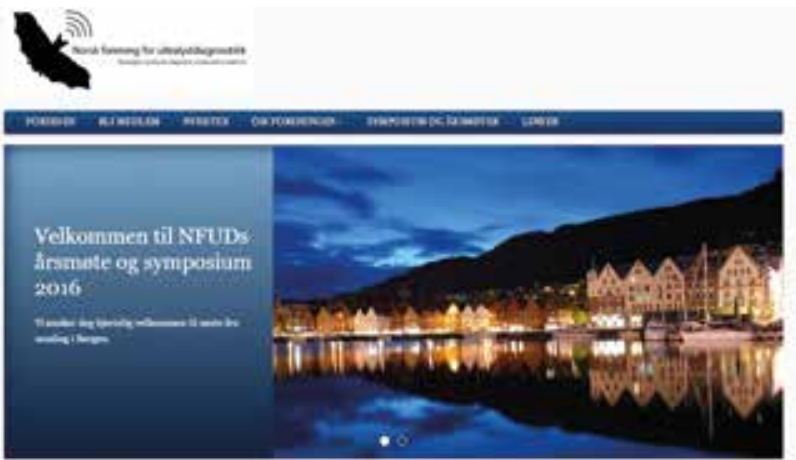

\section{\&in}

ititem dis xrop

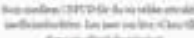

in

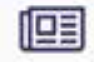

Desominow

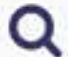

tineminte ber sent
Fig. 1 NFUD har ny nettside!
Med den nye nettsiden var tiden også moden for en oppdatert logo. Etter en engasjert diskusjon falt valget på logoen, som fra nå av kommer til å stå for foreningen for alle ultralydinteresserte i Norge.

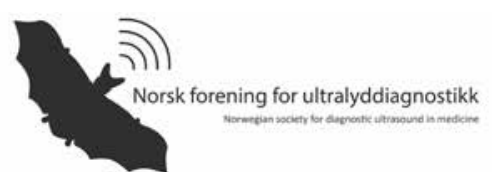

Fig. 2 NFUD har ny logo! 